ISSN: $2637-4668$

\title{
Plastic in Brick Application
}

\author{
Siti Nabilah Amir and Nur Zulaikha Yusof* \\ Department of Civil \& Environmental Engineering, Universiti Teknologi, Malaysia
}

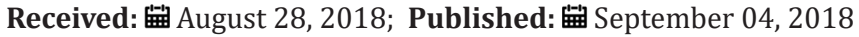

*Corresponding author: Nur Zulaikha Yusof, Department of Civil \& Environmental Engineering, Universiti Teknologi, Petronas, Seri Iskandar Perak, Malaysia

\begin{abstract}
This paper outlines the utilization of municipal plastic waste (MPW) in construction industries. Both the MPW and the construction industries are increasing rapidly and world's recycling rate of either Municipal Solid Waste (MSW) or MPW specifically is still low. Production of bricks is non-eco-friendly and a waste generating process because of the greenhouse gases released. Utilizing MPW as construction materials especially in production of bricks is one of a promising step towards a sustainable resources and waste management. Plastic waste can substitute either partially or completely one or more of the materials in brick production. Further research based on recent research and a better understanding in utilization of plastic waste in brick is needed to produce a high durability and quality of bricks as well as to achieve the optimum balance in all aspects especially in terms of cost and functionality.
\end{abstract}

\section{Introduction}

Urbanization caused a vast and rapid growth of construction industries which requires a lot of building materials that utilizes natural resources either in their production plant or as the materials itself. More recently the world concern about the demands for construction materials and the rate production of plastic that increases swiftly every year [1]. In turn, both industries contribute in increasing the MSW. Since the rate of production is projected to double the value in every 10 years, a more sustainable and safer way is needed to be taken into action [2]. Banning or minimizing plastic usage is not practicable to solve the problem as it is nearly impossible for different sectors to run efficiently without plastic. Mining of natural resources on the other hand is an energy waste process as only 900 million tons of raw materials is produced from 6000 million tons of waste generated $[3,4]$. They may be differ in constitution of raw materials but posses the same in contributing to various environmental threats. Hence, utilizing plastic waste in brick production can solve both the MPW and demands for construction materials. Previous studies showed the possibility of using plastic waste in bricks application but the bricks produced are still lacking of durability as a safe construction materials. The aim of this paper is to review the application of plastic waste in bricks.

\section{Review of Research on Application of Plastic Waste in Bricks}

The table layout the use of plastic in manufacturing bricks. Plastic waste has been utilized in various extend producing various properties of bricks and the properties of bricks produced has been assessed following standards provided Table 1.

Table 1: Application of plastic in brick

\begin{tabular}{|c|c|c|c|c|c|c|c|c|}
\hline No. & $\begin{array}{l}\text { Application of } \\
\text { Plastic }\end{array}$ & $\begin{array}{c}\text { Process/ } \\
\text { Other } \\
\text { Materials }\end{array}$ & $\begin{array}{c}\text { Types of } \\
\text { Plastic Used }\end{array}$ & $\begin{array}{c}\text { Brick Size } \\
\text { (mm) }\end{array}$ & $\begin{array}{c}\text { Optimum } \\
\text { Plastic } \\
\text { Content (\%) }\end{array}$ & $\begin{array}{l}\text { Compressive } \\
\text { Strength for } \\
\text { Optimum } \\
\text { Plastic Content } \\
\text { (MPa) }\end{array}$ & $\begin{array}{l}\text { Other Test } \\
\text { Conducted }\end{array}$ & Reference \\
\hline 1 & Binder & $\begin{array}{l}\text { Glycolysis of } \\
\text { PET bottles. }\end{array}$ & PET & $\begin{array}{c}150 \times 150 \mathrm{x} \\
150\end{array}$ & 10 & 28.5 & $\begin{array}{l}\text { Flexural } \\
\text { strength, pull } \\
\text { out test. }\end{array}$ & [5] \\
\hline 2 & Binder & Soil, bitumen. & PET & $\begin{array}{c}200 \times 100 x \\
100\end{array}$ & 70 & 7.82 & $\begin{array}{c}\text { Water } \\
\text { absorption. }\end{array}$ & [6] \\
\hline 3 & Mold & $\begin{array}{l}\text { Pour OPC in PET } \\
\text { bottles. }\end{array}$ & PET & $150 \times 300 \times 75$ & $\begin{array}{l}9 \text { bottles per } \\
\text { block }\end{array}$ & 35 & $\begin{array}{l}\text { Splitting } \\
\text { tensile } \\
\text { strength. }\end{array}$ & [7] \\
\hline
\end{tabular}




\begin{tabular}{|c|c|c|c|c|c|c|c|c|}
\hline 4 & Mold & $\begin{array}{l}\text { Compress PE in } \\
\text { PET bottles. }\end{array}$ & PET, PE & $\begin{array}{l}62.5 \times 201 \\
\times 62.5\end{array}$ & $+220 \mathrm{~g}$ & 40.1 & $\begin{array}{c}\text { Sound } \\
\text { insulation, } \\
\text { light } \\
\text { transmission } \\
\text { test. }\end{array}$ & [8] \\
\hline 5 & Aggregate & $\begin{array}{l}\text { Gravel, sand, } \\
\text { cement. }\end{array}$ & PET & $\begin{array}{c}150 \times 150 \times \\
150\end{array}$ & 25 & 42.2 & $\begin{array}{l}\text { Splitting } \\
\text { tensile and } \\
\text { flexural } \\
\text { strength, } \\
\text { elasticity, } \\
\text { ultrasonic } \\
\text { test. }\end{array}$ & [9] \\
\hline 6 & Aggregate & $\begin{array}{l}\text { Cement, sand, } \\
\text { crushed stones. }\end{array}$ & EPS & $\begin{array}{c}100 \times 100 x \\
100\end{array}$ & 15 & 20.77 & - & {$[10]$} \\
\hline 7 & Aggregate & Clay, cement. & EPS & $\begin{array}{c}100 \times 100 \times \\
100\end{array}$ & 15 & 20.77 & - & [11] \\
\hline 8 & Aggregate & Fly ash, cement. & PW Powder & $\begin{array}{c}150 \times 150 \mathrm{x} \\
150\end{array}$ & 5 & 57.27 & $\begin{array}{l}\text { Fracture } \\
\text { energy, } \\
\text { splitting } \\
\text { tensile, net } \\
\text { flexural, } \\
\text { modulus of } \\
\text { elasticity. }\end{array}$ & [12] \\
\hline 10 & Aggregate & Cement, sand. & PET, PC & $40 \times 40 \times 160$ & 10 & 38 & $\begin{array}{c}\text { Elastic } \\
\text { modulus, } \\
\text { flexural test, } \\
\text { gas apparent } \\
\text { permeability. }\end{array}$ & [14] \\
\hline 11 & Aggregate & $\begin{array}{l}\text { Cement, fine } \\
\text { aggregate, } \\
\text { coarse } \\
\text { aggregate. }\end{array}$ & $\begin{array}{l}\text { Plastic } \\
\text { aggregates }\end{array}$ & $\begin{array}{c}150 \times 150 \times \\
150\end{array}$ & 15 & 14.06 & $\begin{array}{l}\text { Splitting } \\
\text { tensile and } \\
\text { flexural } \\
\text { strength. }\end{array}$ & [15] \\
\hline 12 & Aggregate & $\begin{array}{l}\text { Sand, gravel, } \\
\text { cement. }\end{array}$ & PE & $70 \times 70 \times 280$ & 10 & 24 & $\begin{array}{c}\text { Flexural } \\
\text { strength, } \\
\text { ultrasonic } \\
\text { pulse velocity } \\
\text { test. }\end{array}$ & [16] \\
\hline 13 & Aggregate & $\begin{array}{l}\text { Laterite soil, } \\
\text { bitumen,. }\end{array}$ & PET & $\begin{array}{c}200 \times 100 \times \\
100\end{array}$ & 70 & 8.16 & $\begin{array}{c}\text { Water } \\
\text { absorption. }\end{array}$ & [17] \\
\hline 14 & $\begin{array}{l}\text { Aggregate, } \\
\text { Binder }\end{array}$ & - & PE, BOPP & $220 \times 100 \times 55$ & $\begin{array}{c}5 \mathrm{~kg} \text { of PE and } \\
\text { BOPP }\end{array}$ & 8.91 & - & [18] \\
\hline 15 & Aggregate & $\begin{array}{l}\text { Cement, lime, } \\
\text { sand. }\end{array}$ & PVC & $160 \times 40 \times 40$ & 50 & 24.53 & $\begin{array}{l}\text { Flexural } \\
\text { strength, } \\
\text { water } \\
\text { absorption, } \\
\text { thermal } \\
\text { conductivity, } \\
\text { adhesion. }\end{array}$ & [19] \\
\hline 16 & Aggregate & $\begin{array}{l}\text { Cement, sand, } \\
\text { aluminium } \\
\text { powder, fly ash }\end{array}$ & Melamine & $50 \times 50 \times 50$ & 19 & 5.32 & - & [20] \\
\hline 17 & Aggregate & Cement, sand & HIPS & $50.8 \times 101.6$ & 10 & 32 & $\begin{array}{l}\text { Splitting } \\
\text { tensile } \\
\text { streght, } \\
\text { modulus of } \\
\text { elasticity, } \\
\text { thermal } \\
\text { conductivity, } \\
\text { water vapour } \\
\text { permeability, } \\
\text { resistance to } \\
\text { freezing and } \\
\text { thawing. }\end{array}$ & [20] \\
\hline
\end{tabular}




\begin{tabular}{|c|c|c|c|c|c|c|c|c|}
\hline 18 & Aggregate & $\begin{array}{c}\text { Cement, } \\
\text { silica fume, } \\
\text { superplasticizer, } \\
\text { sand, crushed } \\
\text { blue granite. }\end{array}$ & EPS & $\begin{array}{c}100 \times 100 \\
\times 100\end{array}$ & 40 & 21 & $\begin{array}{l}\text { Water and } \\
\text { chloride } \\
\text { permeability, } \\
\text { splitting } \\
\text { tensile } \\
\text { strength, } \\
\text { potential } \\
\text { corrosion rate. }\end{array}$ & [20] \\
\hline
\end{tabular}

\section{Discussion}

Previous studies showed the possibility of using plastic as binder with the aid of catalyst through depolymerization of PET to replace cement. Extensive studies of PET as aggregate is more common in compared to other plastic waste. From the table, it showed a significant decrease in compressive strength is observed for more than $50 \%$ replacement of binder with PET waste. In fact that PET is thermoplastic, poor bond is created between the matrix and the aggregates and over stress may result in debonding of bricks and structural failure [21]. Increasing the amount of PET increases the softening point of the bricks produced. However, if the amount of plastic waste which acts as binder is too low, the residual unfilled voids will increase and in turn, increasing the water absorption as well as decreasing its compressive strength. When plastic waste is used as a mold, it can be clearly seen that it can withstand a high compressive strength in compared to using it as binder. However, lacking of compaction of plastic waste in plastic waste bottle may result in entrapped air that will contribute to a low compressive strength to the structure. A slight amount of entrapped air is enough to disrupt the structure of the bricks. Incorporating plastic waste as an aggregate is more common in compared to other methods. A few other materials are added to increase the durability of the bricks produced. Using an optimum amount of plastic waste as an aggregate generally shows an acceptable compressive strength. Expanded PS has a flexural properties that is important for buildings built on a problematic soils as the incorporation of expanded PS reduces the cracks appearance on building structure. Normal bricks do not posses this properties. In addition, bricks that are incorporated with expanded PS as aggregate are lighter and it can retain its strength due to its less permeable properties that helps to inhibit hydration. When PVC is used as aggregates, a low compressive strength can be observed and cracks were rapidly observed around the PVC particles because of the modulus mismatch as PVC posses a lower elastic modulus in compared to the cement. The durability of plastic bricks depend on the amount of plastic incorporated in the mixture. An extensive reviews for the study of waste in construction has been highlighted [21,22]. With the right formulation, plastic waste can be a great substitution for raw materials extracted from natural origin.

\section{Conclusion}

A few conclusions can be drawn based on the review of studies on application of plastic in bricks;

a) A variety of plastic waste has been used in many ways in bricks production. The compressive strength of the bricks produced comply the standard outlined, which is more than the acceptable range outlined.

b) A suitable proportion between plastic waste and other materials used need to be optimized to meet the standard outlined for manufacturing of bricks. Further research and development is needed to improve the quality and durability of plastic bricks.

\section{References}

1. Kissi E, Sadick MA, Agyemang DY (2018) Drivers militating against the pricing of sustainable construction materials: The Ghanaian quantity surveyors perspective. Case Studies in Construction Materials 8: 507516.

2. Silvarrey LD, Phan AN (2016) Kinetic study of municipal plastic waste. International Journal of Hydrogen Energy 41(37): 16352-16364.

3. Whitmore A (2006) The emperors new clothes: Sustainable mining? Journal of Cleaner Production 14(3-4): 309-314.

4. Hilson G (2000) Pollution prevention and cleaner production in the mining industry: an analysis of current issues. Journal of Cleaner Production 8(2): 119-126.

5. Mahdi F, Abbas H, Khan AA (2010) Strength characteristics of polymer mortar and concrete using different compositions of resins derived from post-consumer PET bottles. Constr Build Mater 24: 25-36.

6. Hiremath PM, Shetty S (2014) Utilization of waste plastic in manufacturing of plastic-soil bricks. International Journal of Technology Enhancement and Emerging Engineering Research 2(4): 2347-4289.

7. Muyen Z, Barna TN, Hoque MN (2016) Strength properties of plastic bottle bricks and their suitability as construction materials in Bangladesh. Progressive Agriculture 27(3): 362-368.

8. Taaffe J, O Sullivan S, Rahman ME, Pakrashi V (2014) Experimental characterisation of Polyethylene Terephthalate (PET) bottle Ecobricks. Materials \& Design 60: 50-56.

9. Rahmani E, Dehestani M, Beygi MHA, Allahyari H, Nikbin IM (2013) On the mechanical properties of concrete containing waste PET particles. Construction and Building Materials 47: 1302-1308.

10. Cadere CA, Barbuta M, Rosca B, Serbanoiu AA, Burlacu A, et al. (2018) Engineering properties of concrete with polystyrene granules. Procedia Manufacturing 22: 288-293.

11. Xu Y, Jiang L, Xu J, Li Y (2012) Mechanical properties of expanded polystyrene lightweight aggregate concrete and brick. Construction and Building Materials 27(1): 32-38.

12. Gesoglu M, Güneyisi E, Hansu O, Etli S, Alhassan M (2017) Mechanical and fracture characteristics of self-compacting concretes containing different percentage of plastic waste powder. Construction and Building Materials 140: 562-569.

13. Saadun A, Mutalib AA, Hamid R, Mussa MH (2016) Behaviour of polypropylene fiber reinforced concrete under dynamic impact load. Journal of Engineering Science and Technology 11(5): 684-693.

14. Hannawi K, Kamali Bernard S, Prince W (2010) Physical and mechanical properties of mortars containing PET and PC waste aggregates. Waste management 30(11): 2312-2320. 
15. Anumol S, Elson J (2015) Study on the performance of plastic as replacement of aggregates. International Journal of Engineering Research and Technology 4(11): 187-190.

16. Ghernouti Y, Rabehi B, Safi B, Chaid R (2014) Use of recycled plastic bag waste in the concrete. Journal of International Scientific Publications: Materials, Methods and Technologies 8(1): 480-487.

17. Maneeth PD, Pramod K, Kishor Kumar SS (2014) Utilization of Waste Plastic in Manufacturing of Plastic-Soil Bricks. International Journal of Engineering Research \&Technology 3(8): 529-536.

18. Shimali S (2017) Bricks from waste plastic. International Journal of Advanced Research 5(1): 2839-2845.
19. Aciu C, Ilutiu Varvara DA, Manea DL, Orban YA, Babota F (2018) Recycling of plastic waste materials in the composition of ecological mortars. Procedia Manufacturing 22: 274-279.

20. Sharma R, Bansal PP (2016) Use of different forms of waste plastic in concrete-a review. Journal of Cleaner Production 112(1): 473-482.

21. Gautam PK, Kalla P, Jethoo AS, Agrawal R, Singh H (2018) Sustainable use of waste in flexible pavement: A review. Construction and Building Materials 180: 239-253.

22. Murmu AL, Patel A (2018) Towards sustainable bricks production: An overview. Construction and Building Materials 165: 112-125.

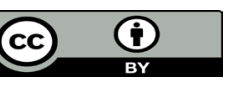

This work is licensed under Creative Commons Attribution 4.0 License

To Submit Your Article Click Here: Submit Article

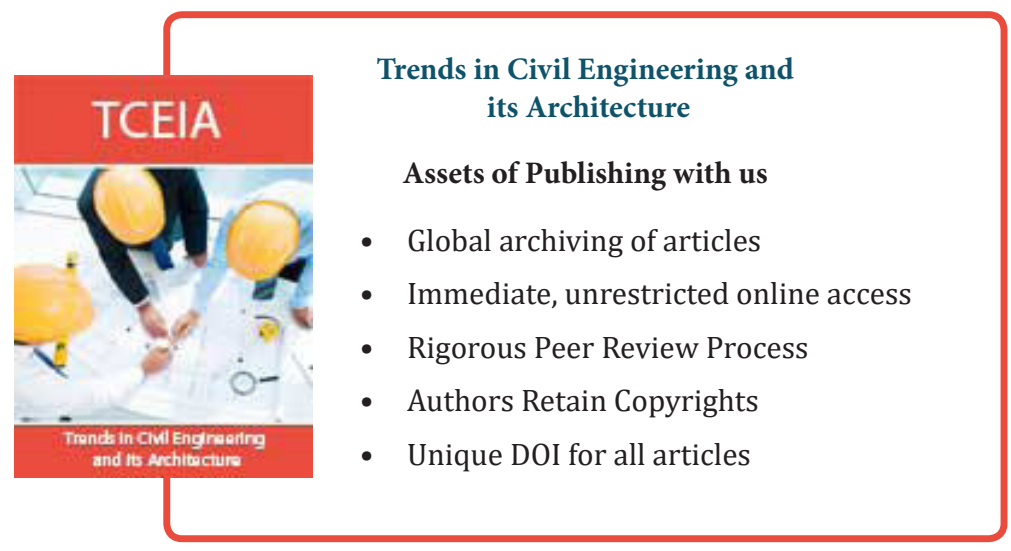

